\title{
Micronutrient Status in Soil and Sorghum (Sorghum bicolor (L.) Moench) Tissues in Daro Labu District, West Hararghe Zone of Oromia Region, Eastern Ethiopia
}

\author{
Tadele Geremu ${ }^{1,}$, Lemma Wogi ${ }^{2}$, Samuel Feyissa ${ }^{2}$ \\ ${ }^{1}$ Oromia Agricultural Research Institute, Fitche Agricultural Research Centre, Soil Fertility Improvement and Problematic Soil Research \\ Team, Fitche, Ethiopia \\ ${ }^{2}$ Haramaya University, School of Natural Resources Management and Environmental Sciences, Haramaya, Ethiopia
}

Email address:

bekgeremu@gmail.com (T. Geremu)

${ }^{*}$ Corresponding author

\section{To cite this article:}

Tadele Geremu, Lemma Wogi, Samuel Feyissa. Micronutrient Status in Soil and Sorghum (Sorghum bicolor (L.) Moench) Tissues in Daro Labu District, West Hararghe Zone of Oromia Region, Eastern Ethiopia. Journal of Chemical, Environmental and Biological Engineering. Vol. 5, No. 1, 2021, pp. 23-36. doi: 10.11648/j.jcebe.20210501.14

Received: July 26, 2019; Accepted: January 9, 2021; Published: March 22, 2021

\begin{abstract}
Updated information on status of soil fertility and the soil plant nutrient relationship is important for soil fertility improvement and subsequently increases crop yields. The study was conducted to assess soil fertility status of sorghum fields and micronutrient concentration in sorghum tissues and examine the relationship between soil and sorghum tissue test micronutrient at Daro Labu district, Eastern Ethiopia. Twelve sorghum growing fields from four kebeles were selected purposively. Field survey was conducted to collect general information about soil fertility management practices and record spatial data. A total of 12 composite soil samples from the depth of $0-20 \mathrm{~cm}$ and 12 sorghum tissue samples were collected. The data were analyzed by using SPSS version 20. The soil texture was sandy clay loam and sandy loam. Soil bulk density was ranged from 1.35 to $1.53 \mathrm{~g}$ $\mathrm{cm}^{-3}$ within an acceptable range. The total porosity of soil was ranged from 41.49 to $45.27 \%$. The soils were very low in OM content with values ranging from 0.60 to $1.18 \%$. The TN content of soil was ranged from 0.06 to $0.14 \%$ which was low. The soils were better in their available $\mathrm{P}$ content. The $\mathrm{CEC}$ of soil ranged from medium to high. Exchangeable $\mathrm{Ca}$ and $\mathrm{Mg}$ were found to be high and medium respectively. Exchangeable $\mathrm{K}$ was low to medium which showed deficiency of $\mathrm{K}$. The soil had adequate level of DTPA extractable Fe and Mn whereas deficiency of $\mathrm{Cu}$ and $\mathrm{B}$ was recorded. The $75 \%$ of soil was showed $\mathrm{Zn}$ deficiency. Sorghum tissue had adequate concentration of $\mathrm{Fe}$ and $\mathrm{Mn}$. However, $66.67 \%, 16.67 \%$ and $58.33 \%$ of sorghum tissues were deficient with $\mathrm{Cu}\left(0.35-10.53 \mathrm{mg} \mathrm{kg}^{-1}\right), \mathrm{Zn}\left(7.06-20.39 \mathrm{mg} \mathrm{kg}^{-1}\right)$ and $\mathrm{B}\left(0.18-4.69 \mathrm{mg} \mathrm{kg}^{-1}\right)$ concentration respectively. The extractable $\mathrm{Fe}, \mathrm{Mn}, \mathrm{Cu}, \mathrm{Zn}$ and $\mathrm{B}$ concentration in a plant tissue were positively correlated with their respective soil micronutrients. The soil of the study areas were at normal condition in terms of the studied soil physical properties. The data regarding chemical fertility parameters indicated that $\mathrm{OM}, \mathrm{TN}, \mathrm{P}, \mathrm{K}, \mathrm{Cu}, \mathrm{Zn}$ and $\mathrm{B}$ are the main limiting factors for crop production. Therefore, application of organic materials (compost, vermicompost, FYM, crop residue management) and balanced minerals fertilizers containing $\mathrm{K}, \mathrm{Cu}, \mathrm{Zn}$ and $\mathrm{B}$ could be recommended. Moreover, further studies on application rates of those fertilizers by considering soil type and crop variety are suggested.
\end{abstract}

Keywords: Adequate, Daro Labu, Deficiency, Micronutrients, Soil Fertility, Sorghum Tissue

\section{Introduction}

Depletion of soil fertility is increasingly being recognized as a fundamental biophysical root cause for declining food security in the smallholder farmers of Sub-Saharan Africa (SSA) [71]. Continuous cropping and inadequate replacement of nutrients removed in harvested materials or lose through erosion and leaching has been the major causes of soil fertility decline [46]. This is particularly evident in the intensively cultivated areas. In Ethiopia where $50-80 \%$ of the animal manure and $70-90 \%$ of the crop residues are removed from the farm and/or used for fuel, soil fertility is 
seriously declining and needs intervention to reverse. In addition to this the loss of soil nutrients in Ethiopia is related to cultural practices such as low fertilizer use, removal of vegetative cover (such as straw or stubble) and burning plant residues or the annual burning of vegetation on grazing land [49].

Depletion of soil fertility leads to declining crop yields and rise in the number of food insecure people [19]. Compared to other causes of soil fertility depletion; soil erosion and nutrient mining can be easily reversed through soil conservation practices and addition of organic and inorganic fertilizers. Based on soil macronutrient survey conducted by Murphy [54] indicates that nitrogen $(\mathrm{N})$ and phosphorus (P) were found to be deficient in many parts of the country. Therefore, a recommendation was made to use the two fertilizers (DAP and Urea) across the country for crop production. However, fertilizers containing micronutrients has not been applied to the soil, because since then little or no attention has not been given to fertilizing the soil with micro nutrients thus leading to unbalanced fertilization and poor nutrient management and crop quality [77].

Soil fertility is an immense constraint to cereal production in Africa [63]. Sorghum (Sorghum bicolor L. Moench) is a viable food grain for millions of people who live in marginal areas of Africa, South Asia and Central America [1]. In Ethiopia, sorghum is third important crop after teff (Eragrostis tef) in terms of total area production. Its production accounts about $16.89 \%$ of the $87.48 \%$ annual cereal production in Ethiopia [21]. In Oromia region, where the study area located, about 20.8 million quintals of sorghum grain were produced during 2018 main cropping season on around 7 hundred thousand hectare [21]. The average grain yield of sorghum in Oromia region is about 28.30 quintals $\mathrm{ha}^{-1}$ well below the industrialized world [21]. A whole range of growth-reducing factors are responsible for this low grain yield. The inherent low soil fertility is hugely blamed for the low yields. These soils are not rich inorganic matter. In addition, little or no litter is added back to the soil due to complete removal of crop residues since farmers used sorghum leaves and stems as a forage for animals. The Stover is also used as construction material. Thus, repeated cultivation and harvest constitute depletion of nutrients and OM.

The drive for targeting higher agricultural production needs a balanced use of nutrients which otherwise create problems of soil fertility exhaustion and nutrient imbalances not only of major but also of secondary and micronutrients [59]. Whenever either of the nutrients is deficient it resulted in abnormal growth, which sometimes cause complete crop failure. Thus, micronutrient deficiency and toxicity can reduce plant yield [68]. Besides, grain and flower formation does not take place in severe deficiency [56]. Therefore, correcting micronutrient deficiencies through balanced fertilization promotes yield of crops [77].

The studies revealed that judicious use of nitrogenous and phosphatic fertilizers in the intensive cropping system may cause the quick depletion of micronutrients in soils [41]. In addition to this, the availability of micronutrient to plant growth is highly dependent on some soil factors such as organic matter content, adsorptive surface, soil $\mathrm{pH}$, lime content, soil texture, topography and nutrient interactions in the soil $[56,26]$.

The status of soil micronutrients in agricultural soils and adjusting their availability to plants through balanced fertilization is expected to increase crop productivity. Currently, the fertility assessment and fertilizer recommendation work for the majority of the country's agricultural land has been completed. Accordingly, in addition to nitrogen and phosphorus deficiency, Boron is highly limiting micro nutrients and in some areas $\mathrm{Zn}$ and $\mathrm{Fe}$ are a potential limiting micronutrient for crop production in Daro labu district. However soil plant micronutrient relationship has not been studied and there is no information on their relationship.

Soil and plant analysis are the commonly used methods to evaluate the soil fertility status. However, the use of plant analysis in this respect has been very limited [39]. According to Ekbladh [23] and Memon et al. [47], the major reasons mentioned for low adoption of plant analysis are environmental variations and plant related factors such as soil type, soil moisture, climate, plant developmental stage, variety etc. Despite these limitations, plant analysis was found to be superior in telling the actual nutrient status of soils since it uses the plant itself as a nutrient extractor [38]. As a result, combining the two methods is vitally important in order to get a better picture of the nutrient status, nutrient interactions and to make viable fertilizer recommendations [47, 45]. In Ethiopia, there are only few soil fertility assessment have been supported by plant tissue analysis [7, $28,38,31,14,43]$. Hence, in this study plant tissue analysis was conducted to support soil data. Therefore, this study was initiated with the following objectives.

General objectives;

1. To assess soil fertility status of sorghum fields and micronutrient status of sorghum tissues and examine the relationship between soil and sorghum tissue test micronutrient status in the study area.

Specific objectives

1. To assess soil fertility status of sorghum growing fields in the study area

2. To determine micronutrient concentration in the tissues of sorghum grown in the study area.

3. To examine the relationship between soil and sorghum tissue micronutrient concentration in the study area.

\section{Material and Methods}

\subsection{Description of the Study Area}

The study was conducted in Daro labu districts, West Hararghe Zone, Oromia National Regional State of Ethiopia. The district is located between $08^{\circ} 19^{\prime} 15^{\prime \prime}$ and $08^{\circ} 42^{\prime} 55^{\prime \prime} \mathrm{N}$ and $40^{\circ} 10^{\prime} 00^{\prime \prime}$ to $40^{\circ} 50^{\prime} 00^{\prime \prime} \mathrm{E}$. The altitude of the study area ranges between 1350 and 2450 meter above sea level 
(m.a.s.1). Eight years mean annual rainfall is $1094 \mathrm{~mm}$ and has a bimodal rainfall distribution pattern. The short rainy season usually starts in March and extends to May, while the main/long rainy season stretches from end of June to September. The annual minimum and maximum temperatures are 14 and $26^{\circ} \mathrm{C}$ respectively and the annual mean temperature is $20^{\circ} \mathrm{C}$ (Figure 2). The major soil type of the study area is Nitisols and its textural class is sandy clay loam which is reddish in color. The agricultural activities in the district are mainly characterized by the presence of subsistence mixed farming system of both crop and livestock production. The major cereal crops grown are sorghum (Sorghum bicolor. L) and maize (Zea mays). Khat (Catha Edulis) and coffee (Coffea) is the main cash crop grown in the study area. The farming system is mainly based on continuous cultivation without any fallow periods.

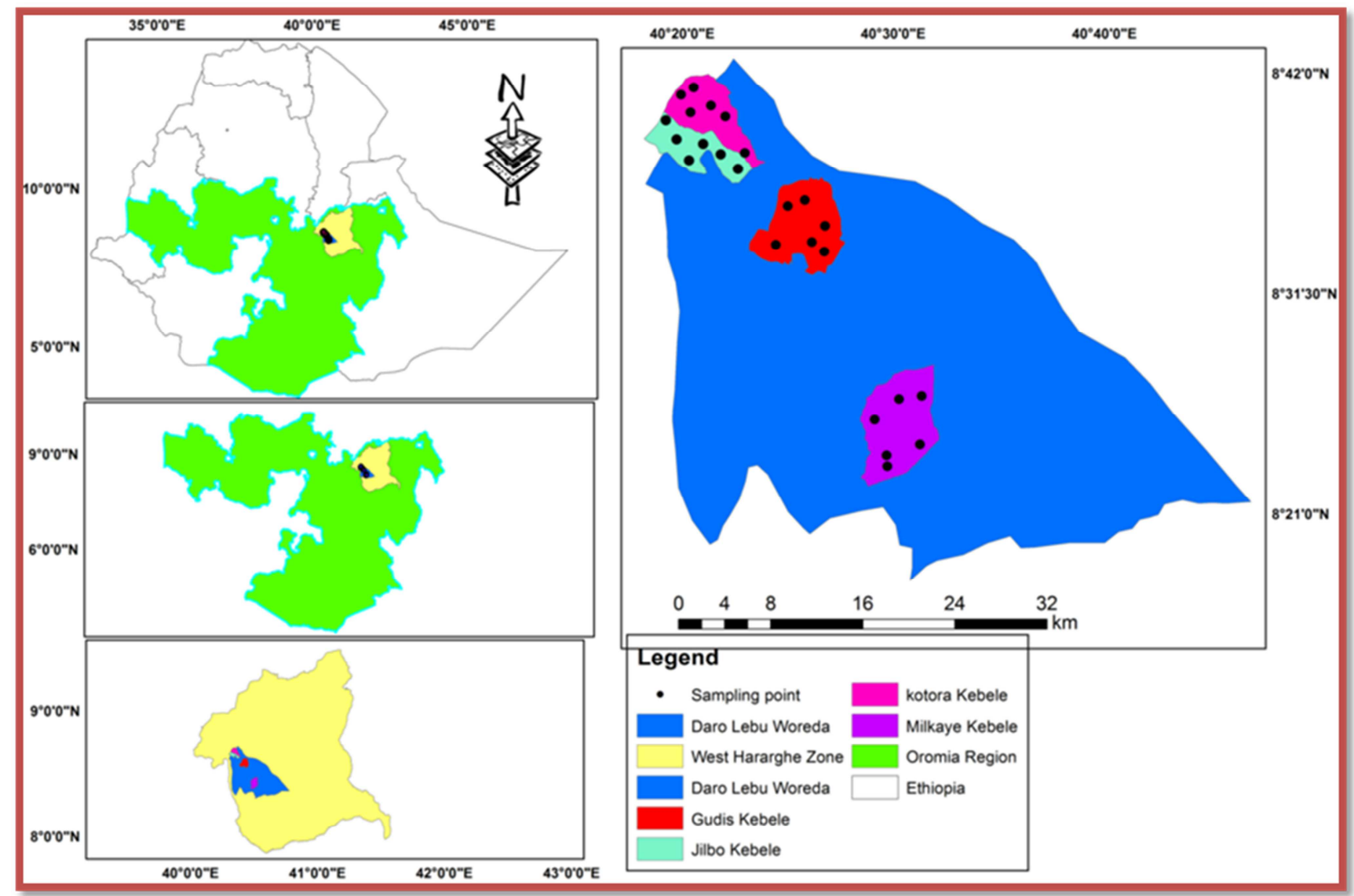

Figure 1. Map of the study area.

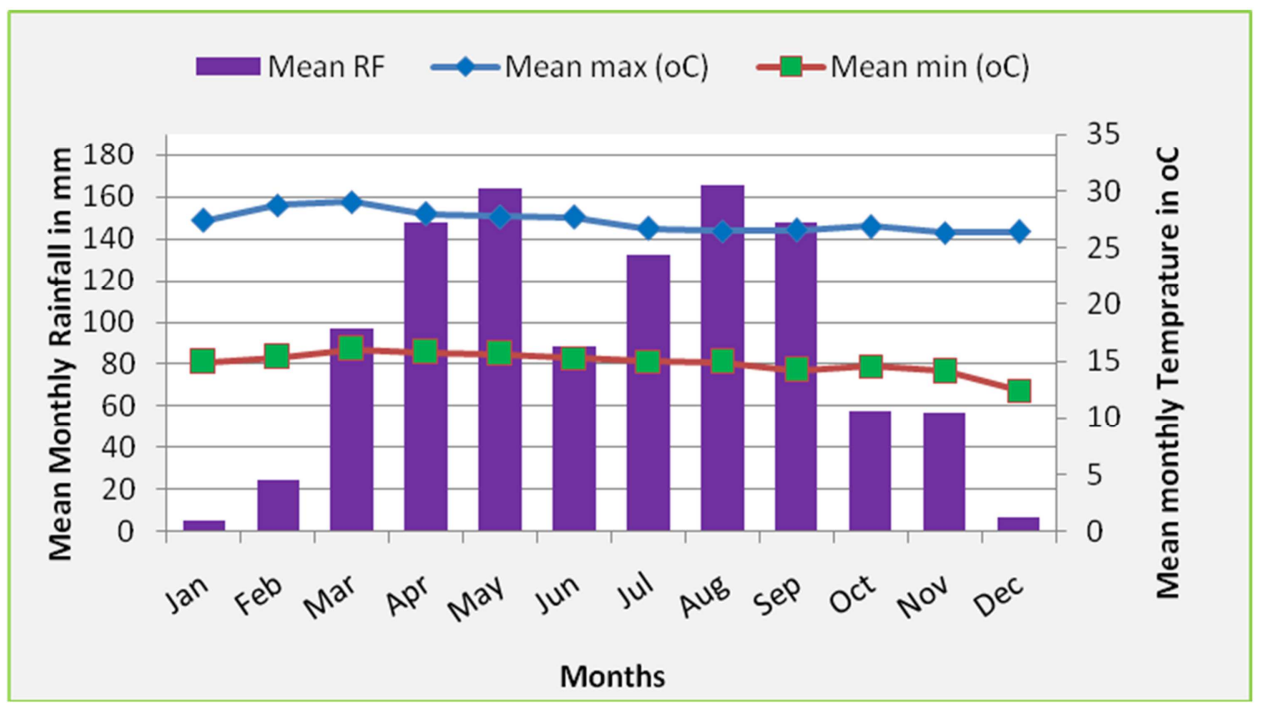

Figure 2. Mean monthly rainfall, maximum and minimum temperatures of the study area from 2010-2018 (Mechara Agricultural Research Center Meteorological station). 


\subsection{Site Selection, Soil and Plant Tissue Sample Collection}

Sampling site selection was performed based on potential of sorghum production areas in the districts. Accordingly four kebeles were selected and from each kebeles three farmers field was selected based on the willingness of the farmers. A total of 12 farmers field were selected from four kebeles.

From each selected farmers` field soil samples were collected. Soil samples were taken from $0-20 \mathrm{~cm}$ depth. The disturbed and undisturbed soil samples were taken using augur and core sampler, respectively. At each sampling point, one composite soil sample was collected from 20 sub sample within $15 \mathrm{~m}$ radius in a circle method. Generally, 240 sub samples were collected to make 12 composite soil samples based on complexity of topography and variability of the soil. From each field, additional information such as topography, slope gradients, longitude, latitude and soil fertility management practices (residue management, type and amount of fertilizers used and dominant previous crop) were collected using a short structured questionnaire in order to get general information about the plots. Soil samples were not collected from restricted areas such as animal dung accumulation places, poorly drained and any other places that cannot give representative soil samples. The composite soil samples were prepared from thoroughly mixed auger sub samples. After mixing approximately $1 \mathrm{~kg}$ of the composite samples with proper labeling on each sampling bag and samples were transported to laboratory for analysis.

Table 1. Physiographic characteristics and soil fertility management practices of the study area (Where; Mgt=management, FYM=Farm yard manure, m.a.s.l=meter above sea level).

\begin{tabular}{|c|c|c|c|c|c|c|c|c|}
\hline \multirow{2}{*}{ Location/site } & \multirow{2}{*}{ Major crop } & \multirow{2}{*}{$\begin{array}{l}\text { Altitude } \\
\text { m.a.s.l }\end{array}$} & \multirow{2}{*}{ Slope (\%) } & \multirow{2}{*}{ Previous crop } & \multirow{2}{*}{ Residue mgt } & \multicolumn{2}{|c|}{ Fertilizer used $\left(\mathrm{kg} \mathrm{ha}^{-1}\right)$} & \multirow{2}{*}{$\begin{array}{l}\text { ton } \text { ha }^{-1} \\
\text { FYM } \\
\end{array}$} \\
\hline & & & & & & NPS & Urea & \\
\hline Milkaye & Sorghum & 1665 & 4 & Sorghum & Cleared & 12.5 & 0 & 0.15 \\
\hline Gudis & Sorghum & 1697 & 6 & Sorghum & Cleared & 7 & 0 & 0 \\
\hline Kotora & Sorghum & 1726 & 8 & Sorghum & Cleared & 12.5 & 0 & 0 \\
\hline Jilbo & Sorghum & 1810 & 12 & Sorghum & Cleared & 10 & 5 & 0 \\
\hline
\end{tabular}

Sorghum tissue sample were collected from the same plots from where soil samples was collected. Three replicated sorghum tissue samples from each kebeles were collected at appropriate stage. The second top leaf of sorghum is best indicators of mineral nutrients [60]. Thus, sorghum tissue at heading stage, the second leaf from top of the plant was collected. Accordingly, 20 sub plant tissue samples were collected within $15 \mathrm{~m}$ radius in a circle method to make one composite tissue sample. Therefore, 240 tissue sub samples were collected to make 12 composite samples from four kebeles.

\subsection{Soil and Plant Tissue Sample Preparation and Analysis}

The collected soil samples were air dried and ground using mortar and pestle and passed through a $2 \mathrm{~mm}$ sieve for soil physico chemical analysis except for TN and OC which was sieved by a $0.5 \mathrm{~mm}$ sieve after a careful removal of plant parts and other unwanted materials.

The particle size distribution of the soils was analyzed using Bouyoucos hydrometer method as outlined by Bouyoucos [16]. Soil textural class names were determined following the textural triangle of USDA system as described by Rowell [61]. The bulk density, from undisturbed soil samples was determined using the core method after drying the soil samples in an oven at $105^{\circ} \mathrm{C}$ to a constant weight [15]. The core sampled soils was oven dried and the bulk density (BD) calculated by dividing the mass of the oven dry soil (g) by the respective volume $\left(\mathrm{cm}^{-3}\right)$ as it exists naturally under field conditions. Pycrometer method was used to determine soil particle density [15]. Total porosity was estimated from the values of $\mathrm{BD}$ and $\mathrm{PD}$ as:

$$
T P(\%)=\left(1-{ }_{P D}^{B D}\right) * 100
$$

Soil $\mathrm{pH}$ was measured by $\mathrm{pH}$ meter in the supernatant suspension of 1:2.5 soils: water ratio [72]. Soil organic carbon content of the soil was determined by potassium dichromate wet oxidation procedure [75]. Soil organic matter was calculated from soil organic carbon by multiplying with a coefficient of 1.724 following the assumptions that organic matter is composed of $58 \%$ organic carbon. Total nitrogen (TN) content of the soil was determined by wet digestion procedures of the Kjeldahl method [15]. Available phosphorus (Av. P) was determined calorimetrically using UV spectrophotometer after the extraction of soil sample with $0.5 \mathrm{M}$ sodium bicarbonate adjusted at $\mathrm{pH} 8.5$ following the Olsen extraction method [58].

Exchangeable cations $(\mathrm{Ca}, \mathrm{Mg}, \mathrm{K}$ and $\mathrm{Na}$ ) were determined after extracting the soil samples by 1normal ammonium acetate $\left(1 \mathrm{~N} \mathrm{NH}_{4} \mathrm{OAc}\right)$ solution at $\mathrm{pH}$ 7.0. Exchangeable $\mathrm{Ca}$ and $\mathrm{Mg}$ in the extract were measured by atomic absorption spectrophotometer (AAS) whilst $\mathrm{K}$ and $\mathrm{Na}$ were read using flame photometer from the same extract [61]. The CEC was determined from the same soil that was leached with ammonium acetate through distillation and titration of ammonia, after washing down of excess ammonium acetate by ethyl alcohol to remove excess salts followed by leaching with sodium chloride to displace the adsorbed $\left(\mathrm{NH}_{4}{ }^{+}\right)$as described by Sahlemedhin and Taye [62]. The percent base saturation of the soils was calculated as the percentage of the sum of exchangeable cations $(\mathrm{Ca}, \mathrm{Mg}, \mathrm{K}$ and $\mathrm{Na})$ to the $\mathrm{CEC}$ and multiplying by 100 as shown in the below equation:

$$
P B S={ }_{C E C}^{(C a+M g+N a+K) * 100}
$$

Extractable micronutrients $(\mathrm{Fe}, \mathrm{Mn}, \mathrm{Zn}$ and $\mathrm{Cu}$ ) were extracted by DTPA method as described by Okalebo et al. [57]. The amounts of the micronutrients in the extract were determined by atomic absorption spectrophotometer (AAS). Boron (B) was extracted by hot water [12]. The extracted $\mathrm{B}$ was measured 
calorimetrically using Azomethine- $\mathrm{H}$ reagent and its concentration was analyzed by using UV spectrophotometer [13].

On the other hand, plant leaves were first washed with distilled water, oven dried at $70^{\circ} \mathrm{C}$ for 48 hours to a constant weight, ground, passed through $2 \mathrm{~mm}$ sieve and placed in paper bags [76]. Micronutrient concentration ( $\mathrm{Fe}, \mathrm{Mn}, \mathrm{Cu}, \mathrm{Zn}$ and Hot water soluble boron) in plant tissues samples was analyzed after dry ashing process [18]. The oven dried ground plant tissue sample was ashed in a muffle furnace at $550^{\circ} \mathrm{C}$ for $6 \mathrm{hrs}$. Subsequently, Hot water soluble B was measured by colorimetry using Azomethine-H reagent and its concentration was determined using UV spectrophotometer while Fe, Mn, $\mathrm{Cu}$ and $\mathrm{Zn}$ concentration in a plant tissue was determined by using Atomic Absorption Spectrophotometer (AAS) [13].

\subsection{Statistical Analysis}

Data analysis was carried out using Statistical Package for Social Sciences (SPSS) software version 20. The mean soil analytical results were interpreted as very low, low, medium, high and very high using standard ratings. Correlation analysis was performed to assess relationships among soil and plant micronutrient contents.

\section{Results and Discussion}

\subsection{Soil Physical Properties}

\subsubsection{Soil Particle Size Distribution}

The soil particle size distributions of the study area were ranged from 55 to $74 \%$ for sand, 11 to $21 \%$ for silt and 15 to $25 \%$ for clay (Table 2). The highest mean values of sand $72.33 \%$ and the lowest mean values of silt $11.67 \%$ and clay $16.00 \%$ fractions was recorded at Jilbo site whereas, the highest mean values of silt $22 \%$ and clay $20 \%$ and the lowest mean values of sand $58 \%$ fraction was recorded at Milkaye site. The mean particle size distribution is in the order of sand $>$ clay $>$ silt. The textural class were varied from sandy clay loam to sandy loam according to USDA soil texture classification system described by Rowell [61]; where sandy loam was a dominant (Table 2).

The most probable reasons for the slight variation in their particle size distribution might be due to differences in slope gradient and elevation (Table 1). From this study, it was found that soils at lower elevation and slope gradient have higher clay and silt content than soil at higher elevation and slope gradient which is indicating that clay and silt fraction was transported from higher slope and subsequently deposited to lower slope through the process of soil erosion. Kedir et al. [42] reported that silt and clay fraction was accumulated at lower slope due to soil erosion.

\subsubsection{Bulk, Particle Densities and Total Porosity}

The mean values of soil bulk densities (BD) were varied from 1.35 to $1.53 \mathrm{~g} \mathrm{~cm}^{-3}$. Relatively, the highest $\left(1.52 \mathrm{~g} \mathrm{~cm}^{-3}\right)$ and the lowest $\left(1.36 \mathrm{~g} \mathrm{~cm}^{-3}\right)$ mean values of BD were recorded at Jilbo and Milkaye site respectively in the study area (Table 2). The slight variation of soil BD might be due to variation of SOM and texture. Therefore, the possible reason for the lowest BD recorded at milkaye site could be due to relatively higher $\mathrm{OM}$ contents and clay fractions as compared to other sites. However, the relatively higher BD registered at Jilbo site is probably due to higher percentage of sand and lower OM content of soil. Pearson correlation analysis reveals that, Clay fraction $(\mathrm{r}=-0.871)$ and $\mathrm{OM}(\mathrm{r}=-0.778)$ content of soils had showed highly significant $(\mathrm{p}<0.01)$ negative correlation with bulk density (Table 7). Usmael [69] also reported a linear negative relationship between OM and bulk density and clay fraction for soils of the Becheke sub watershed, Haramaya district, Easter Ethiopia. In general, the soil BD of the study area were found to be with an acceptable range for sandy loam and sandy clay loam which is less than $1.61 \mathrm{~g} \mathrm{~cm}^{-3}$ [9]. Based on the critical level given by Hazelton and Murphy [37], the soil BD of the current study area was moderate. This indicates the existence of loose soil conditions in the study area; therefore, the soils of the study area have good structure.

The values of soil particle density (PD) were ranged from 2.37 to $2.59 \mathrm{~g} \mathrm{~cm}^{-3}$. Comparatively, the highest $\left(2.58 \mathrm{~g} \mathrm{~cm}^{-3}\right)$ and the lowest $\left(2.38 \mathrm{~g} \mathrm{~cm}^{-3}\right)$ mean values of PD were registered at Jilbo and Milkaye site for soil of sorghum growing fields (Table 2). The most probable reasons for the slight variation in their soil PD might be due to differences in OM content and heavy minerals in the soil. The highest PD recorded at Jilbo site could be due to the presence of relatively high sand content, presence of heavy minerals of iron and lower SOM content (Tables $3 \& 5$ ).

Soil OM content of soils had showed highly significant $(\mathrm{p}<0.01)$ negative correlation $(\mathrm{r}=-0.928)$ and sand fraction had showed highly significant $(\mathrm{p}<0.01)$ positive correlation $(\mathrm{r}=0.956)$ with PD as shown in Pearson Correlation (Table 7). Iron content of soil had showed positive correlation $(\mathrm{r}=0.474)$ with PD. This is in line with the finding of Mulugeta [53] who reported that PD increased due to the presence of high sand content and heavy metals of Fe.

Table 2. Mean values of some soil physical properties in Daro Labu district.

\begin{tabular}{|c|c|c|c|c|c|c|c|}
\hline Kebele/ site & Sand $(\%)$ & Silt (\%) & Clay (\%) & Soil texture & BD $\left(\mathrm{g} \mathrm{cm}^{-3}\right)$ & PD $\left(\mathrm{g} \mathrm{cm}^{-3}\right)$ & TP $(\%)$ \\
\hline Milkaye & $58.00 \pm 3.00$ & $20.00 \pm 1.00$ & $22.00 \pm 2.65$ & SCL & $1.36 \pm 0.02$ & $2.38 \pm 0.01$ & $42.68 \pm 0.93$ \\
\hline Gudis & $68.67 \pm 1.53$ & $13.67 \pm 0.58$ & $17.67 \pm 2.08$ & SL & $1.49 \pm 0.02$ & $2.54 \pm 0.04$ & $41.25 \pm 0.73$ \\
\hline Kotora & $64.67 \pm 4.93$ & $16.33 \pm 2.31$ & $19.00 \pm 2.65$ & SL & $1.42 \pm 0.02$ & $2.45 \pm 0.04$ & $42.11 \pm 1.57$ \\
\hline Jilbo & $72.33 \pm 1.53$ & $11.67 \pm 0.58$ & $16.00 \pm 1.00$ & SL & $1.52 \pm 0.01$ & $2.58 \pm 0.01$ & $40.86 \pm 0.35$ \\
\hline Total & $65.92 \pm 6.14$ & $15.42 \pm 3.45$ & $18.67 \pm 2.96$ & SL & $1.45 \pm 0.07$ & $2.49 \pm 0.08$ & $41.73 \pm 1.13$ \\
\hline Range & $55.00-74.0$ & $11.00-21.0$ & $15.00-25.0$ & & $1.35-1.53$ & $2.37-2.59$ & $40.30-43.51$ \\
\hline CV $(\%)$ & 9.31 & 22.37 & 15.85 & & 4.83 & 3.21 & 2.71 \\
\hline
\end{tabular}

Mean $\pm \mathrm{SD}, \mathrm{BD}=$ Bulk density, $\mathrm{PD}=$ Particle density, $\mathrm{TP}=$ Total porosity, $\mathrm{CV}=$ Coefficient of variation, $\mathrm{SCL}=\mathrm{Sandy}$ clay loam, $\mathrm{SL}=\mathrm{Sandy}$ loam 
Total porosity of the soil was ranged from 40.30 to $43.51 \%$ Relatively, the highest (42.68\%) and lowest (40.86\%) mean values of total porosity were registered at Milkaye and Jilbo sites respectively (Table 2). According to the FAO [32] rating, the percent total porosity of soil in the study areas was rated as very high $>40 \%$.

\subsection{Soil Chemical Properties}

\subsubsection{Soil Reaction (pH)}

The recorded soil $\mathrm{pH}$ of the study area was extended from 6.31 to 6.93 . Relatively, the highest (6.90) and the lowest (6.32) mean $\mathrm{pH}$ values were registered at Milkaye and Jilbo site respectively (Table 3 ). In general, the soil $\mathrm{pH}$ of study area was categorized under slightly acidic to neutral as per the rating of Tekalign [66]. The variation of soil $\mathrm{pH}$ mean values might be due to differences in slope gradients, elevation, application of acid forming fertilizers and soil texture (Tables $1 \& 2$ ). In line with this finding Mohammed et al., [50] reported that soils in higher altitudes and slopes had lower $\mathrm{pH}$ values, probably suggesting washing out of soil basic cations. Cardelli et al., [17] and Alexandra et al., [8] who stated that soil $\mathrm{pH}$ values were significantly lower due to the application of $\mathrm{NH}_{4}^{+}$sourced fertilizers that nitrifies $\mathrm{NH}_{4}{ }^{+}$. According to Gazey and Davies [34], $\mathrm{pH}$ between 5.5 and 7.0 was considered as an ideal for plant growth. Thus, the $\mathrm{pH}$ values of soils of the study area are ideal for plant growth and the availability of most of plant nutrients might not be affected with this $\mathrm{pH}$ ranges.

\subsubsection{Soil Organic Carbon, Total Nitrogen and C: $N$ Ratio}

The values of soil organic carbon (OC) across the study area ranged from 0.35 to $0.69 \%$. Comparatively the highest $(0.66 \%)$ and lowest $(0.39 \%)$ mean values of OC were recorded at Milkaye and Jilbo site respectively (Table 3). According to the rating suggested by Tekalign [66], the soil organic carbon content of the study area can be categorized under very low $(<0.86 \%)$ which needs urgent improvements via application of organic materials such as compost, vermicompost, surface residue management etc. Total removal of crop residues due to a number of competing ends such as animal feed, fuel, construction and sell to others to generate income is common practices which lower the amount of SOC and not applying organic fertilizers to replace the amounts mineralized, immobilized and lost by erosion in the study areas. In addition to this, the most probable source of variation in soil OC contents among the fields might be due to variation in altitude, slope gradients, cropping system, FYM application (Table 1). Fields of steep slopes (Jilbo site) with severe soil erosion due to steep slope gradients could contribute to lower OC contents as the OC depletes through removal of the surface soils. Similarly, Musefa [55] reported that high level of SOM recorded at lower slope due to OC accumulation. In line with this, many authors [3, 65, 38, 29] reported that complete removal of crop residues without adding external organic inputs were considered as the major reasons for low OC status of cultivated lands.

The soil total nitrogen content was extended from 0.06 to $0.14 \%$. Relatively, the highest $(0.1 \%)$ mean values of TN were recorded at Milkaye and Kotora site while the lowest $(0.07 \%)$ mean values were recorded at Jilbo site (Table 3 ). According to the rating suggested by Tekalign [66], the soils of the study area were found to be low in their TN. Relatively the lowest soil TN content recorded Jilbo site could be attributed to relatively low OM content, steep slope gradient and high percentage of sand fraction which exacerbate loss of TN. These results are also supported by Zhihui et al. [79] who stated that application of organic materials increased OM content of soil. Mesfin [49] report indicate that, soil erosion due to steep slopes and heavy rainfall as well as leaching, may have contributed to nitrogen loss.

The soil Carbon to nitrogen ratio was ranged from 4.14 to 8.83. Comparatively, the highest (6.63) and lowest (5.70) mean values of $\mathrm{C}$ : $\mathrm{N}$ ratio was registered at Milkaye and Jilbo site respectively (Table 3 ). According to $\mathrm{C}$ : $\mathrm{N}$ ratio rating suggested by Landon [44], the $\mathrm{C}$ : $\mathrm{N}$ ratio of soils of the study area were categorized as very low $(<8)$. This is clearly indicated that Very low $\mathrm{C}$ : $\mathrm{N}$ ratio of the study areas could be attributed to low organic carbon as compared to total nitrogen. Musefa [55] reported similar findings.

Table 3. Mean values of soil chemical properties in Daro Labu district.

\begin{tabular}{|c|c|c|c|c|c|}
\hline Kebele/ site & $\mathrm{pH}\left(\mathrm{H}_{2} \mathrm{O}\right)$ & OC (\%) & TN (\%) & $C: N$ & Av. P (mg kg $\left.{ }^{-1}\right)$ \\
\hline Milkaye & $6.90 \pm 0.03$ & $0.66 \pm 0.02$ & $0.10 \pm 0.02$ & $6.63 \pm 1.55$ & $11.46 \pm 0.67$ \\
\hline Gudis & $6.49 \pm 0.06$ & $0.47 \pm 0.14$ & $0.08 \pm 0.02$ & $6.12 \pm 1.90$ & $10.25 \pm 0.33$ \\
\hline Kotora & $6.67 \pm 0.06$ & $0.57 \pm 0.10$ & $0.10 \pm 0.04$ & $5.71 \pm 2.04$ & $11.13 \pm 0.91$ \\
\hline Jilbo & $6.32 \pm 0.01$ & $0.39 \pm 0.04$ & $0.07 \pm 0.01$ & $5.70 \pm 1.42$ & $9.75 \pm 1.25$ \\
\hline Total & $6.60 \pm 0.23$ & $0.52 \pm 0.13$ & $0.09 \pm 0.03$ & $6.43 \pm 1.61$ & $10.65 \pm 1.02$ \\
\hline Range & $6.31-6.93$ & $0.35-0.69$ & $0.06-0.14$ & $4.14-8.83$ & $8.43-12.07$ \\
\hline $\mathrm{CV}(\%)$ & 3.48 & 25 & 33.33 & 25.04 & 9.58 \\
\hline
\end{tabular}

Mean $\pm \mathrm{SD}, \mathrm{pH}=$ power of hydrogen, $\mathrm{OC}=$ Organic Carbon, $\mathrm{TN}=$ Total nitrogen, $\mathrm{C}: \mathrm{N}=$ Carbon to nitrogen ratio, Ava. $\mathrm{P}=\mathrm{Available}$ phosphorus, $\mathrm{CV}=\mathrm{Coefficient}$ of variation

\subsubsection{Available Phosphorus}

The soil available $\mathrm{P}$ of sorghum growing fields was ranged from 8.43 to $12.07 \mathrm{mg} \mathrm{kg}$. Comparatively, the highest $\left(11.46 \mathrm{mg} \mathrm{kg}^{-1}\right)$ and the lowest $\left(9.75 \mathrm{mg} \mathrm{kg}^{-1}\right)$ mean values of Olsen extractable $\mathrm{P}$ were recorded at Milkaye and Jilbo site respectively (Table 3 ). Based on the rating suggested by Cottenie [20], the available $\mathrm{P}$ contents of soil in the study area were found to be low $\left(<10 \mathrm{mg} \mathrm{kg}^{-1}\right)$ to medium (10-17 $\left.\mathrm{mg} \mathrm{kg}{ }^{-1}\right)$. The variability in soil available $\mathrm{P}$ content might be due to type and rate of organic and inorganic fertilizers and slope gradient, which can cause downward movement of $\mathrm{P}$ 
with runoff water from top slope and accumulated at the bottom slope among farms (Table 1). Accordingly, the highest available $\mathrm{P}$ at Milkaye site could be due to relatively high amount $\mathrm{P}$ containing fertilizer application, low elevation, gentle slope gradients and relatively high OM contents. These results are in agreement with the report of Wakene [74] and Gebeyaw [35] who indicated that available $P$ in cultivated land was higher due to mineral $\mathrm{P}$ fertilization resulted in the building up of plant available $\mathrm{P}$ on top soils compared to non-fertilized plots. However, OM is not necessarily the primary supplying source of available $\mathrm{P}$, but it retains available $\mathrm{P}$ against loss through erosion. This is best described by positive and highly significant $(\mathrm{r}=0.682, \mathrm{p}<0.01)$ correlation between Avail. P and OC (Table 7).

\subsubsection{Cation Exchange Capacity (CEC)}

The soil CEC of the study area was ranged from 23.20 to
27.60 Cmol (+) $\mathrm{kg}^{-1}$. Relatively the highest $(27.13 \mathrm{Cmol}(+)$ $\left.\mathrm{kg}^{-1}\right)$ and the lowest $\left(23.53 \mathrm{Cmol}(+) \mathrm{kg}^{-1}\right)$ mean values of CEC were registered at Milkaye and Jilbo site respectively (Table 4). Based on the rating suggested by Hazelton and Murphy [37], the soils of the study area varied from medium $\left(12-25 \mathrm{Cmol}^{(+)} \mathrm{kg}^{-1}\right)$ to high $\left(25-40 \mathrm{Cmol}(+) \mathrm{kg}^{-1}\right)$ in their CEC. The variation in CEC values of the studied soils is attributable to variation in soil organic matter content and percentage of clay fraction. The higher soil CEC value at Milkaye site might be attributed to the increase in clay contents and OM. Pearson correlation analysis indicated strongly significant $(\mathrm{p}<0.01)$ and positively relationship between CEC and OC $(\mathrm{r}=0.750)$, CEC and clay fraction $(\mathrm{r}=0.817)$ (Table 7). The result in agreement with this, Abayneh [2] found that negative charge derived from the clay minerals and OM increases the CEC of soils.

Table 4. Mean values of CEC, exchangeable cations and PBS of soil in Daro Labu district.

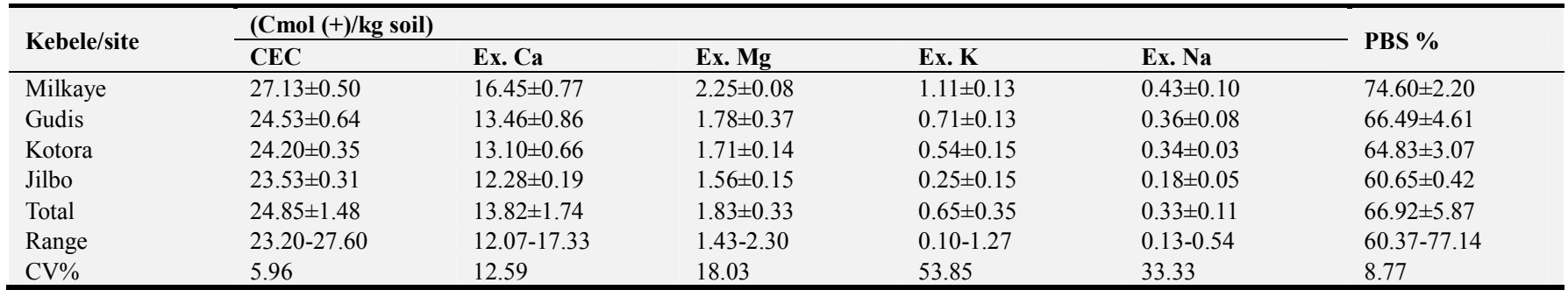

$\mathrm{Mean} \pm \mathrm{SD}, \mathrm{CEC}=$ Cation exchange capacity, Ex=Exchangeable, $\mathrm{PBS}=$ Percent base saturation, $\mathrm{CV}=\mathrm{Coefficient}$ of variation

\subsubsection{Exchangeable Basic Cations and Percent Base Saturation (PBS)}

The data regards exchangeable bases showed that, relatively the highest mean values of exchangeable $\mathrm{Ca}(16.45$ $\left.\mathrm{Cmol}(+) \mathrm{kg}^{-1}\right), \mathrm{Mg}\left(2.25 \mathrm{Cmol}(+) \mathrm{kg}^{-1}\right), \mathrm{K}(1.11 \mathrm{Cmol}(+)$ $\left.\mathrm{kg}^{-1}\right)$ and $\mathrm{Na}\left(0.43 \mathrm{Cmol}(+) \mathrm{kg}^{-1}\right)$ were recorded at Milkaye site, whereas, the lowest mean values of exchangeable $\mathrm{Ca}$ $\left(12.28 \mathrm{Cmol}(+) \mathrm{kg}^{-1}\right), \mathrm{Mg}\left(1.56 \mathrm{Cmol}(+) \mathrm{kg}^{-1}\right), \mathrm{K}(0.25$ $\left.\mathrm{Cmol}(+) \mathrm{kg}^{-1}\right)$ and $\mathrm{Na}\left(0.18 \mathrm{Cmol}(+) \mathrm{kg}^{-1}\right)$ were registered at Jilbo site under (Table 4).

According to the ratings set by FAO [32], the exchangeable $\mathrm{Ca}$ was grouped as high and $\mathrm{Mg}$ was categorized as medium in the study area. The status of exchangeable $\mathrm{K}$ were ranged from medium at Milkaye and Gudis site to low at Kotora and Jilbo site indicating that the soils are deficient in $K$. The exchangeable $\mathrm{Na}$ in the study areas were grouped as medium except at Jilbo site which was low status.

The lower exchangeable bases at Jilbo site might be attributed to higher slope gradients, low OM contents and high percentage of sand particles which contribute to accelerate leaching of basic cations. Similarly, Achalu et al. [4] reported that, lower concentrations of exchangeable $\mathrm{Ca}$, $\mathrm{Mg}, \mathrm{K}$ and $\mathrm{Na}$ contents recorded in soils of cultivated land could be attributed to low OM content and leaching of basic cations from top soils of cultivated land.

From the fertility point of view, exchangeable $\mathrm{Ca}, \mathrm{Mg}$ and also $\mathrm{K}$ at Milkaye and Gudis were not limiting nutrients to crop production. However, the low level of exchangeable K at Kotora and Jilbo site might be due to relatively its lower $\mathrm{pH}$ values in addition to its lower OM contents. The results were in agreement with the findings reported by Alemayehu Tadesse [6] and Mesfin Abebe [48] that the low levels of exchangeable $\mathrm{K}$ observed under acidic soils and intensive cultivation. Wakene (2001) also reported K deficiency in Nitisols of Bako area. However the results were disagrees with the common belief that Ethiopian soils are rich in potassium [54]. Barber [11] reported that the critical level of exchangeable $\mathrm{K}$ in the soil for most crops of $\mathrm{K}$ fertilizer requirement is $0.38 \mathrm{Cmol}(+) \mathrm{kg}^{-1}$ and therefore, the content of exchangeable $\mathrm{K}$ for soils of sorghum fields at Jilbo site which is below the critical level and insufficient for optimum crop production. Therefore, the soils required application of $\mathrm{K}$ containing fertilizers and OM improvement.

The computed PBS indicated that, the highest $(74.60 \%)$ and lowest $(60.65 \%)$ mean values of PBS were recorded at Milkaye and Jilbo site (Table 4). According to the ratings set by Hazelton and Murphy [37], the PBS of soil of the study areas were found to be High (60-80\%). In general, soils with high PBS are considered relatively more fertile because many of the bases that contribute to higher PBS are essential macro plant nutrients [36]. Accordingly, the soils of the study area had high and considered as fertile soils with regards to exchangeable cations especially $\mathrm{Ca}$ and $\mathrm{Mg}$.

\subsubsection{Extractable Micronutrients (Fe, $\mathrm{Mn}, \mathrm{Cu}, \mathrm{Zn}$ and $\mathrm{B})$ of Soil}

The values of DTPA extractable micronutrients were 
ranged for $\mathrm{Fe}$ (8.47 to $\left.16 \mathrm{mg} \mathrm{kg}^{-1}\right), \mathrm{Mn}$ (6.51 to $13.01 \mathrm{mg} \mathrm{kg}$ $\left.{ }^{1}\right), \mathrm{Cu}\left(0.39\right.$ to $\left.1.18 \mathrm{mg} \mathrm{kg}^{-1}\right), \mathrm{Zn}\left(0.04\right.$ to $\left.0.86 \mathrm{mg} \mathrm{kg}^{-1}\right)$ and hot water soluble extractable B $\left(0.10\right.$ to $\left.0.20 \mathrm{mg} \mathrm{kg}^{-1}\right)$. Relatively, the highest mean value of extractable Fe (15.29 $\mathrm{mg} \mathrm{kg}^{-1}$ ) was recorded at jilbo, while Mn (12.13 $\left.\mathrm{mg} \mathrm{kg}^{-1}\right), \mathrm{Zn}$ $\left(0.57 \mathrm{mg} \mathrm{kg}^{-1}\right)$, and $\mathrm{B}\left(0.21 \mathrm{mg} \mathrm{kg}^{-1}\right)$ were registered at Milkaye and $\mathrm{Cu}\left(0.92 \mathrm{mgkg}^{-1}\right)$ was registered at Kotora site. On the other hand, the lowest mean values of extractable $\mathrm{Fe}$ (9.57 $\left.\mathrm{mg} \mathrm{kg}^{-1}\right)$ was recorded at Milkaye site while $\mathrm{Mn}(7.15$ $\left.\mathrm{mg} \mathrm{kg}{ }^{-1}\right), \mathrm{Cu}\left(0.44 \mathrm{mg} \mathrm{kg}{ }^{-1}\right)$ and $\mathrm{B}\left(0.12 \mathrm{mg} \mathrm{kg}^{-1}\right)$ were recorded at Jilbo and also the lowest $\mathrm{Zn}\left(0.17 \mathrm{mg} \mathrm{kg}^{-1}\right)$ was recorded at Gudis site (Table 5).

According to the rating described by Jones [39], 100\% soils of the study areas were categorized as high and medium in their DTPA extracted Fe and Mn contents respectively. Similarly, adequate amount of extractable Fe and Mn status in most Ethiopian soil was registered by many researchers $[28,38,51,65,24,25,73,43]$. Therefore, the soil of the study areas had adequate levels of extractable Fe and Mn and their application in the form of fertilizer is not required unless their possible deficiencies due to nutrient interaction or other factors lowers their status are observed.
The low level of extractable micronutrients $(\mathrm{Cu}, \mathrm{Zn}$ and $\mathrm{B})$ could be attributed to low OM, high percentage of sand fraction and poor soil management in the study areas. Similarly, Wajahat et al., [72] reported that most sandy soils are acutely deficient in micronutrients compared to clay soils. Low OM content of soil is contributed to lower extractable soil micronutrient [74].

On the other hand, $100 \%$ soil were categorized as low and very low level in their extractable $\mathrm{Cu}$ and hot water soluble $\mathrm{B}$ according to the rating suggested by Karltun et al. [40]. Extractable $\mathrm{Zn}$ was medium at Milkaye, low at Kotora and Jilbo and very low level at the remaining sites. Thus $100 \%$ of soils of the study areas were deficient in their extractable $\mathrm{Cu}$ and $\mathrm{B}$. On the other hand, $75 \%$ soils of sorghum growing fields were deficient in their extractable $\mathrm{Zn}$ contents. In agreement with the finding of the study, $\mathrm{Cu}$ deficiency was observed in Ethiopian soil [25, 28, 77]. Extractable Zn and B deficiencies were reported as a common soil fertility problem in many soils of Ethiopia [28, 38, 65, 24, 25, 78, 67, 26, 43]. Therefore, in the study area the use of $\mathrm{Cu}, \mathrm{Zn}$ and $\mathrm{B}$ containing fertilizers could be recommended.

Table 5. Mean values of selected micronutrients of soil in Daro Labu district.

\begin{tabular}{lllll}
\hline \multirow{2}{*}{ Kebele/site } & \multicolumn{1}{l}{$\mathbf{M g ~ k g}^{-1}$} & & & \\
\cline { 2 - 5 } & Fe & Mn & Cu & Zn \\
\hline Milkaye & $9.57 \pm 1.01$ & $12.13 \pm 0.14$ & $0.81 \pm 0.04$ & $0.57 \pm 0.17$ \\
Gudis & $9.96 \pm 0.75$ & $8.19 \pm 2.52$ & $0.51 \pm 0.10$ & $0.17 \pm 0.04$ \\
Kotora & $13.80 \pm 0.78$ & $10.36 \pm 2.37$ & $0.92 \pm 0.24$ & $0.49 \pm 0.33$ \\
Jilbo & $15.29 \pm 0.93$ & $7.15 \pm 0.37$ & $0.44 \pm 0.05$ & $0.18 \pm 0.02$ \\
Total & $12.16 \pm 2.67$ & $9.46 \pm 2.50$ & $0.67 \pm 0.24$ & 0.25 \\
Range & $8.47-16.00$ & $6.51-13.01$ & $0.39-1.18$ & $0.39 \pm 0.25$ \\
CV\% & 21.96 & 26.43 & 35.82 & $0.04-0.86$ \\
\hline
\end{tabular}

Mean \pm SD, CV $=$ Coefficient of variation

\subsection{Micronutrient Concentration in Sorghum Tissue}

The micronutrient concentrations of sorghum tissues were ranged for $\mathrm{Fe}$ (62.40 to $\left.116.80 \mathrm{mg} \mathrm{kg}^{-1}\right), \mathrm{Mn}$ (23.88 to 38.81 $\left.\mathrm{mg} \mathrm{kg}{ }^{-1}\right), \mathrm{Cu}$ (0.35 to $\left.10.53 \mathrm{mg} \mathrm{kg}^{-1}\right), \mathrm{Zn}$ (7.06 to $20.39 \mathrm{mg}$ $\left.\mathrm{kg}^{-1}\right)$ and $\mathrm{B}\left(0.18\right.$ to $\left.4.69 \mathrm{mg} \mathrm{kg}^{-1}\right)$. Relatively, the highest concentration of $\mathrm{Fe}$ was registered at Jilbo site, whereas, Mn and $\mathrm{B}$ were registered at Milkaye site. Highest concentrations of $\mathrm{Cu}$ and $\mathrm{Zn}$ were recorded at Kotora site. In contrast, the lowest Fe concentrations were recorded at Milkaye site while $\mathrm{Mn}, \mathrm{Cu}, \mathrm{Zn}$ and $\mathrm{B}$ were recorded at Jilbo site (Table 6).

The sorghum tissue concentrations of $\mathrm{Fe}$ and $\mathrm{Mn}$ revealed that $91.67 \%$ of the tissues were found to be within a sufficiency range according to the norms developed by plank and Donohue, [60]. The sufficient concentrations of $\mathrm{Fe}$ and $\mathrm{Mn}$ in sorghum tissue were in agreement with their soil concentration. Similarly, Kehali, [43] reported sufficient and higher $\mathrm{Fe}$ and $\mathrm{Mn}$ concentration in sorghum leaves. $66.67 \%$, $16.67 \%$ and $58.33 \%$ of sorghum tissue were deficient in $\mathrm{Cu}$, $\mathrm{Zn}$ and $\mathrm{B}$ concentration respectively. In contrast to soil $\mathrm{Cu}$ and $\mathrm{B}$ contents that have $100 \%$ deficient, sorghum tissue didn't indicate the whole deficiency while $75 \%$ of $\mathrm{Zn}$ deficiency in soil of sorghum growing fields, only $16.67 \%$ of sorghum tissues was deficient. The present study thus indicated that sorghum plant has ability to absorb the required quantity of those micronutrients from the growing medium within its growing season. In agreement with this finding, plants which have greater root mass and hair, increased micronutrient solubility due to root exudates, influence of soil $\mathrm{pH}$ and acidification of the rhizosphere and other acidic reactions was reported to enhance the availability and uptake of $\mathrm{Cu}, \mathrm{B}, \mathrm{Fe}, \mathrm{Mn}$ and $\mathrm{Zn}$ by roots [5, 22, 27, 36]. In addition to this, the optimum level of manganese increases the uptake of copper.

Many of the soil physico chemical properties revealed significant correlations of varying degrees and directions among each other (Table 7). For instance, BD and PD was highly significantly $(\mathrm{p} \leq 0.01)$ and negatively associated with OM. Similarly, bulk density also highly significantly ( $\mathrm{p} \leq$ 0.01 ) and negatively correlated with total porosity.

Soil $\mathrm{pH}$ was highly significantly $(\mathrm{p} \leq 0.01)$ and positively correlated with exchangeable $\mathrm{Ca}, \mathrm{Mg}, \mathrm{k}$ and $\mathrm{Na}$ and negatively associated with extractable Fe. It had also highly significantly $(\mathrm{p} \leq 0.01)$ and positively correlated with CEC, $\mathrm{OM}$ and significantly $(\mathrm{p} \leq 0.05)$ correlated with total nitrogen. This is because the solubility and availability of bases 
forming cations increase at higher $\mathrm{pH}$ and that of $\mathrm{Fe}$ decreases with increase in soil $\mathrm{pH}$. Higher concentrations of exchangeable bases $(\mathrm{Ca}, \mathrm{Mg}, \mathrm{K}$ and $\mathrm{Na}$ ) are apparently responsible for the relatively increases soil $\mathrm{pH}$ values observed in this study. The positive relationship between $\mathrm{pH}$ and $\mathrm{OM}$ may indicate that $\mathrm{OM}$ retains exchangeable bases that possibly increase soil $\mathrm{pH}$.

Table 6. Mean values of micronutrient concentration of sorghum tissue in Daro Labu district.

\begin{tabular}{|c|c|c|c|c|c|}
\hline \multirow{2}{*}{ Kebele/site } & \multicolumn{5}{|l|}{$\mathrm{Mg} \mathrm{kg}^{-1}$} \\
\hline & $\mathrm{Fe}$ & Mn & $\mathbf{C u}$ & Zn & B \\
\hline Milkaye & $65.6 \pm 2.88$ & $35.82 \pm 1.49$ & $3.51 \pm 1.75$ & $14.64 \pm 3.17$ & $3.07 \pm 1.48$ \\
\hline Gudis & $83.47 \pm 11.79$ & $27.36 \pm 4.80$ & $1.52 \pm 0.27$ & $14.64 \pm 0.45$ & $0.90 \pm 1.10$ \\
\hline Jilbo & $104.53 \pm 11.12$ & $27.36 \pm 3.11$ & $1.17 \pm 0.71$ & $10.98 \pm 3.42$ & $0.36 \pm 0.18$ \\
\hline Total & $88.00 \pm 18.56$ & $30.60 \pm 5.19$ & $2.81 \pm 2.78$ & $14.31 \pm 3.26$ & $1.53 \pm 1.55$ \\
\hline Range & $62.40-116.80$ & $23.88-38.81$ & $0.35-10.53$ & $7.06-20.39$ & $0.18-4.69$ \\
\hline
\end{tabular}

mean $\pm \mathrm{SD}, \mathrm{CV}=$ Coefficient of variation

Correlations between Soil Physico chemical Properties

OM had strong significant $(\mathrm{P} \leq 0.01)$ positive relationships with hot water soluble $\mathrm{B}, \mathrm{Cu}, \mathrm{Mn}$ and clay. Available $\mathrm{P}$ and $\mathrm{OM}$ contents of the soils had significant $(\mathrm{P} \leq 0.05)$ positive relationships with each other and strongly negatively associated with sand. The positive relationship between available $\mathrm{P}$ and $\mathrm{OM}$ may indicate the contribution of $\mathrm{OM}$ contents to retain loss of available $\mathrm{P}$ through soil erosion. Therefore, in the management of available $\mathrm{P}$ of soils it may be essential to maintain and increase the level of soil OM.

Table 7. Pearson's correlation matrix among soil physico chemical properties of the study area.

\begin{tabular}{|c|c|c|c|c|c|c|c|c|c|c|}
\hline & BD & PD & TP & Sand & clay & pH & OM & $\mathbf{T N}$ & AvP & CEC \\
\hline $\mathrm{BD}$ & 1 & $.928^{* *}$ & $-.753^{* *}$ & $.822^{* *}$ & $-.871^{* *}$ & $-.980^{* *}$ & $-.778^{* *}$ & $-.669^{*}$ & $-.621^{*}$ & $-.814^{* *}$ \\
\hline PD & & 1 & -.454 & $.956^{* *}$ & $-.934^{* *}$ & $-.941^{* *}$ & $-.928^{* *}$ & -.481 & $-.729^{* *}$ & $-.827^{* *}$ \\
\hline TP & & & 1 & -.276 & .432 & $.683^{*}$ & .221 & $.753^{* *}$ & .190 & .495 \\
\hline Sand & & & & 1 & $-.946^{* *}$ & $-.869^{* *}$ & $-.921^{* *}$ & -.275 & $-.733^{* *}$ & $-.798^{* *}$ \\
\hline clay & & & & & 1 & $.885^{* *}$ & $.815^{* *}$ & .326 & $.773^{* *}$ & $.817^{* *}$ \\
\hline $\mathrm{pH}$ & & & & & & 1 & $.829^{* *}$ & $.595^{*}$ & $.637^{*}$ & $.859^{* *}$ \\
\hline $\mathrm{OM}$ & & & & & & & 1 & .367 & $.682^{*}$ & $.750^{* *}$ \\
\hline AvP & & & & & & & & & 1 & .534 \\
\hline CEC & & & & & & & & & & 1 \\
\hline
\end{tabular}

Table 7. Continued.

\begin{tabular}{|c|c|c|c|c|c|c|c|c|c|}
\hline & Ca & Mg & K & $\mathrm{Na}$ & $\mathbf{F e}$ & Mn & $\mathrm{Cu}$ & Zn & B \\
\hline $\mathrm{BD}$ & $-.815^{* *}$ & $-.715^{* *}$ & $-.749^{* *}$ & $-.724^{* *}$ & .460 & $-.778^{* *}$ & $-.720^{* *}$ & -.474 & $-.737^{* *}$ \\
\hline PD & $-.833^{* *}$ & $-.808^{* *}$ & $-.796^{* *}$ & $-.728^{* *}$ & .474 & $-.930^{* *}$ & $-.847^{* *}$ & $-.654^{*}$ & $-.876^{* *}$ \\
\hline $\mathrm{TP}$ & .487 & .289 & .391 & .449 & -.259 & .218 & .217 & -.019 & .215 \\
\hline Sand & $-.800^{* *}$ & $-.792^{* *}$ & $-.823^{* *}$ & $-.661^{*}$ & $.581^{*}$ & $-.912^{* *}$ & $-.806^{* *}$ & $-.668^{*}$ & $-.887^{* *}$ \\
\hline clay & $.800^{* *}$ & $.708^{* *}$ & $.770^{* *}$ & $.640^{*}$ & -.542 & $.830^{* *}$ & $.758^{* *}$ & $.600^{*}$ & $.767^{* *}$ \\
\hline $\mathrm{pH}$ & $.847^{* *}$ & $.770^{* *}$ & $.818^{* *}$ & $.762^{* *}$ & -.568 & $.799^{* *}$ & $.700^{*}$ & .440 & $.794^{* *}$ \\
\hline $\mathrm{OM}$ & $.778^{* *}$ & $.828^{* *}$ & $.805^{* *}$ & $.748^{* *}$ & -.489 & $.980^{* *}$ & $.840^{* *}$ & $.649^{*}$ & $.952^{* *}$ \\
\hline $\mathrm{AvP}$ & .515 & $.592^{*}$ & .434 & .521 & -.480 & $.696^{*}$ & $.673^{*}$ & .327 & $.629^{*}$ \\
\hline CEC & $.984^{* *}$ & $.874^{* *}$ & $.913^{* *}$ & $.809^{* *}$ & $-.686^{*}$ & $.736^{* *}$ & .441 & .415 & $.738^{* *}$ \\
\hline $\mathrm{Ca}$ & 1 & $.895^{* *}$ & $.932^{* *}$ & $.827^{* *}$ & $-.685^{*}$ & $.782^{* *}$ & .479 & .447 & $.789^{* *}$ \\
\hline $\mathrm{Mg}$ & & 1 & $.828^{* *}$ & $.753^{* *}$ & $-.669^{*}$ & $.831^{* *}$ & .495 & .364 & $.858^{* *}$ \\
\hline K & & & 1 & $.864^{* *}$ & $-.773^{* *}$ & $.777^{* *}$ & .515 & .474 & $.785^{* *}$ \\
\hline $\mathrm{Na}$ & & & & 1 & $-.669^{*}$ & $.726^{* *}$ & .547 & .357 & $.645^{*}$ \\
\hline $\mathrm{Fe}$ & & & & & 1 & -.436 & -.162 & .039 & -.548 \\
\hline $\mathrm{Cu}$ & & & & & & & 1 & $.730^{* *}$ & $.734^{* *}$ \\
\hline $\mathrm{Zn}$ & & & & & & & & 1 & .516 \\
\hline B & & & & & & & & & 1 \\
\hline
\end{tabular}

$*, * *$ Correlation is significant at $\mathrm{p}<0.05$ and 0.01 , respectively

Simple linear correlation analysis also showed that CEC of the soils of the study area showed highly significant $(\mathrm{P} \leq 0.01)$ positive relationships with clay, $\mathrm{OM}$ and exchangeable bases and highly significant $(\mathrm{P} \leq 0.01)$ negative relationships with sand and BD. The relationship between CEC and clay implies that clay is a major contributor for the soil CEC. CEC 
had also significant $(\mathrm{P} \leq 0.05)$ and positive relationships with total N. In addition, all exchangeable cations had strong significant $(\mathrm{P} \leq 0.01)$ positive relationships with each other (Table 7). The extractable Mn content of the soils had strong significant $(\mathrm{P} \leq 0.01)$ positive relationships with $\mathrm{Cu}$ and $\mathrm{B}$ and significant positive interaction $(\mathrm{P} \leq 0.05)$ with $\mathrm{Zn}$. Similarly, extractable $\mathrm{Cu}$ content of the soils had strong significant $(\mathrm{P} \leq 0.01)$ positive relationships with $\mathrm{Zn}$ and $\mathrm{B}$. Extractable $\mathrm{Mn}, \mathrm{Cu}$ and $\mathrm{B}$ had strong significant $(\mathrm{P} \leq 0.01)$ positive relationships with $\mathrm{OM}$ and clay fraction and extractable $\mathrm{Zn}$ had significant interaction $(\mathrm{P} \leq 0.05)$ with $\mathrm{OM}$ and clay fraction of soil (Table 7).

\subsection{Soil and Sorghum Tissue Micronutrient Relationships}

Correlation analysis result between plant and soil micronutrients reveals that the only significant and positive correlation was observed for Fe. Thus, there was significantly $(\mathrm{p} \leq 0.05)$ positive correlation $\left(\mathrm{r}=0.676^{*}\right)$ for $\mathrm{Fe}$ in soil and sorghum tissue. However, sorghum tissue $\mathrm{B}, \mathrm{Mn}, \mathrm{Cu}$ and $\mathrm{Zn}$ didn't show significant correlation with their respective soil nutrients. The presence of non significant correlation indicates that the uptake of micro nutrients not only affected by soil nutrient contents, but might be affected by $\mathrm{pH}$, texture, OM, CEC and other nutrient interaction (Table 8).

Sorghum Fe uptake was negatively $(\mathrm{r}=-0.670)$ significant $(\mathrm{p} \leq 0.05)$ correlation to soil reaction. However, the concentration of $\mathrm{B}, \mathrm{Mn}, \mathrm{Cu}$ and $\mathrm{Zn}$ in sorghum tissue were positively $(r=0.663, r=0.671, r=470$ and $r=0.396$ respectively) correlated to soil $\mathrm{pH}$. On the other hand all micronutrient concentration except $\mathrm{Fe}$ in sorghum tissues has positive correlation with OM, CEC and clay fraction of soil. However, concentration of $\mathrm{Fe}$ in sorghum tissue was negatively correlated to $\mathrm{OM}, \mathrm{CEC}$ and clay fraction (Table 8). The effects of these soil factors on Fe content of sorghum tissues are correlated in a lesser magnitude. This might be partly due to Fe concentration in plant is insensitive to the soil factors. In line with this, FAO [31] reported that Fe concentration in a plant less affected by soil factors, however the effects of soil factors $(\mathrm{pH}, \mathrm{OM}$, texture and $\mathrm{CEC})$ on plant micronutrients except $\mathrm{Fe}$ are similar in magnitude and direction. In addition, the oxidation-reduction conditions of soils are important in determining the behavior of $\mathrm{Fe}$ in soils and its availability to plants.

Antagonistic effects were observed among soil and sorghum tissue micronutrient contents. B concentration in sorghum tissues was negatively correlated with $\mathrm{Fe}(\mathrm{r}=-0.361)$ and $\mathrm{Zn}(\mathrm{r}=-0.383)$ contents of soil. Fe uptake of sorghum had negative correlation with $\mathrm{B}(\mathrm{r}=-0.397), \mathrm{Mn}(\mathrm{r}=-0.257$ and $\mathrm{Cu}$ $(\mathrm{r}=-0.073)$ content of soil. Data regarding Mn uptake of sorghum indicated negative interaction with soil $\mathrm{Fe}(\mathrm{r}=-0.336)$ and $\mathrm{Zn}(\mathrm{r}=-0.436)$ contents. Furthermore, negative correlation of $\mathrm{Zn}$ uptake of sorghum with soil $\mathrm{Fe}(\mathrm{r}=-0.281)$ was recorded (Table 8). Zn content of soil reduced B accumulation in plant tissue and toxicity on plants grown in soils containing adequate B $[52 ; 64]$. Iron uptake is reported to be decreased with the presence of $\mathrm{Cu}$ and $\mathrm{Mn}$ in the growth medium [33]. Aref [10] also reported antagonism between $\mathrm{Zn}$ in the soil and leaf Mn content. The uptake of $\mathrm{Mn}$ has been reported to be inhibited by $\mathrm{Zn}$ in a soil [28].

Table 8. Pearson correlation matrix for relationship between soil and sorghum micronutrients in Daro Labu district.

\begin{tabular}{|c|c|c|c|c|c|c|c|c|c|c|c|c|c|c|c|}
\hline & pH & OM & Sand & clay & CEC & BS & FeS & MnS & $\mathrm{CuS}$ & ZnS & $\mathrm{BSr}$ & FeSr & $\mathrm{MnSr}$ & $\mathrm{CuSr}$ & $\mathrm{ZnSr}$ \\
\hline $\mathrm{pH}$ & 1 & $.829^{*}$ & $-.869^{* *}$ & $.885^{* *}$ & $.859^{* *}$ & $.794^{* *}$ & -.568 & $.799^{* *}$ & $.700^{*}$ & -.247 & $.663^{*}$ & $-.670^{*}$ & $.671^{*}$ & .470 & .396 \\
\hline $\mathrm{OM}$ & & 1 & $-.921^{* *}$ & $.815^{* *}$ & $.750^{* *}$ & $.952^{* *}$ & -.489 & $.980^{* *}$ & $.840^{* *}$ & .118 & .311 & -.344 & .303 & .279 & $.587^{*}$ \\
\hline Sand & & & 1 & $-.946^{* *}$ & $-.798^{* *}$ & $-.887^{* *}$ & $.581^{*}$ & $-.912^{* *}$ & $-.806^{* *}$ & -.052 & -.395 & .504 & -.436 & -.273 & $-.618^{*}$ \\
\hline CEC & & & & & 1 & $.738^{* *}$ & $-.686^{*}$ & $.736^{* *}$ & .441 & -.416 & .554 & $-.715^{* *}$ & .460 & .259 & .133 \\
\hline BS & & & & & & 1 & -.548 & $.938^{* *}$ & $.734^{* *}$ & -.040 & .243 & -.397 & .344 & .240 & .469 \\
\hline $\mathrm{FeS}$ & & & & & & & 1 & -.436 & -.162 & .540 & -.361 & $.676^{*}$ & -.336 & .090 & -.281 \\
\hline $\mathrm{CuS}$ & & & & & & & & & 1 & .449 & .253 & -.073 & .272 & .499 & $.713^{* *}$ \\
\hline $\mathrm{ZnS}$ & & & & & & & & & & 1 & -.383 & $.588^{*}$ & -.436 & .030 & .562 \\
\hline $\mathrm{BSr}$ & & & & & & & & & & & 1 & -.538 & $.863^{* *}$ & .081 & .024 \\
\hline $\mathrm{FeSr}$ & & & & & & & & & & & & 1 & -.517 & -.172 & -.095 \\
\hline $\mathrm{MnSr}$ & & & & & & & & & & & & & 1 & .140 & .016 \\
\hline $\mathrm{CuSr}$ & & & & & & & & & & & & & & 1 & .134 \\
\hline $\mathrm{ZnSr}$ & & & & & & & & & & & & & & & 1 \\
\hline
\end{tabular}

$*, * *$ Correlation is significant at $\mathrm{p}<0.05$ and 0.01 , respectively, $\mathrm{S}=$ soil, $\mathrm{Sr}=$ sorghum

\section{Summary and Conclusion}

Updated information on soil fertility status is important for soil management intervention and subsequently increases crop yields. However, until recently, adequate information on soil fertility status and the relation of micronutrients in soil and sorghum tissue was lacking in Daro Labu district, West Hararghe Zone of Eastern Ethiopia. Hence this study was conducted to assess soil fertility status of sorghum fields and micronutrient status of sorghum tissues and examine the relationship between soil and sorghum tissue test micronutrient status in the study area.

A preliminary field survey was conducted to asses soil fertility management practices (type and amount of fertilizers used), crops grown during previous year and record the spatial data and slope gradient. Four kebeles were selected from the districts based on their potential on sorghum production. Twelve soil samples from $0-20 \mathrm{~cm}$ and twelve 
sorghum tissues at flowering/heading stage were collected from the districts in a circle method.

The soil textural classes of the study area were sandy clay loam and sandy loam. Regarding particle size distribution, sand size fraction followed by clay fraction dominated the study area. Soil bulk density was found to be within the range that is acceptable for the registered textural classes. On the other hand, soil total porosity of the study area was high status which indicates that the soils are porous enough for water movement and good aeration.

Soil reaction $(\mathrm{pH})$ was slightly acidic to neutral in which the ranges are considered as optimum for production of many crops and availability and solubility of plant nutrients. The soil OM and $\mathrm{TN}$ content of the study area were very poor. The status of available $\mathrm{P}$ is better in most of the soils of the study area.

The soil of the study area was medium to high categories in their CEC. Accordingly, the soils were at normal condition in their exchangeable bases $(\mathrm{Ca}, \mathrm{Mg}, \mathrm{K}$ and $\mathrm{Na}$ ) except for at Jilbo and Kotora site which was low, showed K deficiency.

The DTPA extractable Fe and Mn content of soils were high. Therefore, the soil had adequate levels of extractable Fe and $\mathrm{Mn}$. On the other hand, extractable $\mathrm{Cu}$ and $\mathrm{B}$ were categorized as low and hence showed deficiency of those micronutrients. Furthermore, the extractable $\mathrm{Zn}$ content of varied from very low to medium.

Similar to soil analysis, the concentrations of Fe and $\mathrm{Mn}$ in sorghum tissues were found to be within a sufficiency range. In line with this, the soil of the study areas had adequate levels of extractable Fe and Mn. However, the deficiency of $\mathrm{Cu}, \mathrm{B}$ and $\mathrm{Zn}$ was observed in sorghum tissues.

The study indicated that, the uptake of micronutrients is affected by soil $\mathrm{pH}, \mathrm{OM}$, soil texture, $\mathrm{CEC}$ and antagonism (nutrient imbalance) effect of soil micronutrients. Accordingly, Fe uptake of sorghum was negatively affected by several physical and chemical soil properties. Antagonism effect of boron, manganese and copper was observed on Fe uptake of sorghum. The B and Mn uptake of sorghum was negatively affected by high percentage of sand and due to antagonistic effect of soil $\mathrm{Fe}$ and $\mathrm{Zn}$. Sand fraction of soil also negatively affect the $\mathrm{Cu}$ and $\mathrm{Zn}$ uptake of sorghum. In contrast, the micronutrient concentration in sorghum tissue was positively correlated with soil OM, clay fraction and $\mathrm{CEC}$ except $\mathrm{Fe}$ concentration in sorghum tissues which was showed negative association with them.

In conclusion, the soils of the study area are desirable in physical soil properties and exchangeable bases except $\mathrm{K}$ in some areas as well as adequate level of extractable Fe and $\mathrm{Mn}$ content. However, poor chemical properties and deficiency of some extractable micronutrients are identified. Specifically, the soils have problems related to OM, TN, P, K, extractable $\mathrm{Cu}, \mathrm{Zn}$ and $\mathrm{B}$. With regards to plant tissue analysis result, sorghum had adequate level of $\mathrm{Fe}$ and $\mathrm{Mn}$ concentration in their tissues while, $\mathrm{Cu}, \mathrm{Zn}$ and $\mathrm{B}$ concentration is deficient. Hence, application of organic materials (compost, vermicompost, FYM, crop residue management) and balanced minerals fertilizers containing $\mathrm{K}$, $\mathrm{Cu}, \mathrm{Zn}$ and $\mathrm{B}$ could be recommended. Moreover, further studies on application rates of those fertilizers by considering soil type and crop variety are suggested.

\section{Acknowledgements}

I am pleased to express my sincere gratitude to Mr. Habtamu Hailu and Mr. Gabayo Chala for their unlimited help during sample collection. I would also like to express my gratitude to the development agents of kebeles for their facilitation during sample collection. I would like to acknowledge Oromia Agricultural Research Institute (OARI) for financial and material support for the successful completion of the study. Also, I would like to thank Haramaya University Soil Chemistry Laboratory staff members for their valid supports and continuous encouragement in many ways during Laboratory analysis.

\section{References}

[1] AATF (African Agricultural Technology Foundation), 2011. Feasibility Study on Striga Control in Sorghum. Nairobi, African Agricultural Technology Foundation. ISBN 9966775-12-9.

[2] Abayneh Esayas. 2001. Some physico-chemical characteristics of the Raya Valley report. Ethiopian Journal of Natural Resources, 3 (2): 179-193.

[3] Abreha Kidanemariam, Heluf Gebrekidan, Tekalign Mamo, Kibebew Kibret. 2012. Impact of altitude and land use type on some physical and chemical properties of acidic soils in Tsegede highlands, Northern Ethiopia. Open Journal of Soil Science, 2: 223-233.

[4] Achalu Chimdi, Heluf Gebrekidan, Kibebew Kibret and Abi Tadesse. 2012. Status of selected physicochemical properties of soils under different land use systems of Western Oromia, Ethiopia. Journal of Biodiversity and Environmental Sciences, 2 (3): 57-71.

[5] Akhter, N. 2011. Comparison of DRIS and critical level approach for evaluating nutrition status of Wheat in District Hyderabad, Pakistan. PhD dissertation, Faculty of Agriculture, University of Bonn, Bonn, Germany.

[6] Alemayehu Tadesse. 1990. Soil and irrigation management in the state farms. pp. 47-52. In: Proceedings of the First Natural Resources Conservation Conference. Natural Resource Degradation: A Challenge to Ethiopia. Institute of Agricultural Research (IAR), 7-8 Feb 1989. Addis Ababa, Ethiopia.

[7] Alemu Lelago. 2017. Soil fertility mapping and fertilizer recommendation for Damboya, Kecha Bira and Kedida Gemela Woredas, SNNPR, Ethiopia. PhD dissertation, Hawassa University, Hawassa, Ethiopia.

[8] Alexandra, M., Charles, R., Jeangros, B. and Sinaj, S. 2013. Effect of organic fertilizers and reduced-tillage on soil properties, crop nitrogen response and crop yield. Soil and Tillage Research, 126: 11-18.

[9] Amusan, A. A., Shitu, A. K., Makinde, W. O. and Orewole, O. 2001. Assessment of changes in selected soil properties under different land use in Nigeria. Electronic Journal of Environmental, Agricultural and Food chemistry, 8: 03-023. 
[10] Aref, F. 2011. Concentration of zinc and boron in corn leaf as affected by zinc sulfate and boric acid fertilizers in a deficient soil. Life Science Journal, 8 (1): 2-11.

[11] Barber, S. A. 1984. Soil nutrient bioavailability, 1984, New York.

[12] Berger, K. C. and E. Truog, E. 1939. Boron determination in soils and plants. England chemistry analysis, 11: 540-545.

[13] Bingham, F. T. 1982. Boron, Methods of soil analysis, Part 2: Chemical and mineralogical properties. America Society of Agronomy, Madison, WI, USA. p. 431-448.

[14] Birch, H. F. and Desta Hamito. 1971. The fertility status of Ethiopian soils. FAO soils bulletin No 14. Rome.

[15] Blake, C. A. 1965. Methods of soil analysis. Part I, American Society of Agronomy. Madison, Wisconsin, USA. 1572p.

[16] Bouyoucos, G. J. 1962. Hydrometer method improvement for making particle size analysis of soils. Agronomic Journal, 54: 179-186.

[17] Cardelli, R., Marchini, F. and Saviozzi, A. 2012. Soil organic matter characteristics, biochemical activity and antioxidant capacity in mediterranean land use systems. Soil and Tillage Research, 120: 8-14.

[18] Chapman, H. D. and Pratt P. F. 1961. Methods of analysis for soils, plants and water. University of California, Berkeley, CA, USA.

[19] Chillot Yirga and Hassan, RM. 2010. Social costs and incentives for optimal control of soil nutrient depletion in the Central Highlands of Ethiopia. Agricultural System, 103: 153-160.

[20] Cottenie, A. 1980. Soil and plant testing as a basis of fertilizer recommendations. FAO Soil Bulletin 38/2. Food and Agriculture Organization of the United Nations, Rome, Italy.

[21] CSA (Central Statistics Authority), 2018. Agricultural Sample Survey 2017/2018. Report on Area and Production for Major Crops (Private Peasant Holdings, Meher Season). Statistical Bulletin No. 586. Addis Ababa, Ethiopia.

[22] Diatta, J. B. and W. Grzebisz. 2006. Influence of mineral nitrogen forms on heavy metals mobility in two soils. Part I. Polish Journal of Environmental Studies, 15 (2a): 56-62.

[23] Ekbladh, G. 2007. Plant analysis as a tool to determine crop nitrogen status towards leaf area based measurements. Doctoral Thesis, Swedish University of Agricultural Sciences, Uppsala, Sweden.

[24] EthioSIS (Ethiopia Soil Information System). 2014. Soil fertility status and fertilizer recommendation atlas for Tigray regional state, Ethiopia. July, 2014, Addis Ababa, Ethiopia.

[25] EthioSIS (Ethiopia Soil Information System). 2016. Soil fertility status and fertilizer recommendation atlas for Amhara regional state, Ethiopia. August, 2016, Addis Ababa, Ethiopia.

[26] Eyob Tilahun, Kibebew Kibret, Tekalign Mamo and Hailu Shiferaw. 2015. Assessment and mapping of some soil micronutrients status in agricultural land of Alicho-Woriro Woreda, Siltie Zone, Southern Ethiopia. American Journal of Plant Nutrition and Fertilization Technology. 5: 16-25.

[27] Fageria, N. K. and Baligar, V. C. 2005. Enhancing nitrogen use efficiency in crop plants. Advances in Agronomy, 88: 97185.
[28] Fanuel Laekemariam, Kibebew Kibret, Tekalign Mamo and Heluf Gebrekidan. 2016. Soil-Plant nutrient status and their relations in maize-growing fields of Wolaita Zone, Southern Ethiopia, Communications in Soil Science and Plant Analysis. 47: 11, 1343-1356.

[29] Fanuel Laekemariam. 2015. Soil spatial variability analysis, fertility mapping and soil-plant nutrient relationships in Wolita zone, southern region, Ethiopia. $\mathrm{PhD}$ dissertation, Haramaya University, Haramaya, Ethiopia.

[30] FAO (Food and Agriculture Organization), 2006b. Guidelines for Soil Description. FAO, Rome, Italy.

[31] FAO (Food and Agriculture Organization). 1983. Micronutrients. FAO, Fertilizer and Plant Nutrition Bulletin 7. Rome, Italy.

[32] FAO (Food and Agriculture Organization). 2006a. Scaling Soil Nutrient Balances. Fertilizer and Plant Nutrition, Bulletin No. 15. FAO, Rome, Italy.

[33] Follett, R. H., Murphy, L. S. and Donahue. R. L. 1981. Fertilizers and Soil Amendments. Englewood Cliffs, New Jersey: Prentice-Hall.

[34] Gazey, C. and Davies, S. 2009. Soil acidity: A guide for WA Farmers and Consultants. Department of Agriculture and Food, Western Australia, Perth.

[35] Gebeyaw Tilahun. 2007. soil fertility status as influenced by different land uses in maybar areas of South Wello Zone, North Ethiopia. MSc thesis. Haramaya University, Haramaya, Ethiopia.

[36] Havlin, J. L., J. D. Beaton, S. L. Tisdale, and W. L. Nelson. 2009. Soil Fertility and Fertilizers: An Introduction to Nutrient Management, $7^{\text {th }}$ edition. New Jersey, USA: Prentice Hall.

[37] Hazelton, P. and Murphy, B. 2007. Interpreting Soil Test Results. What Do All the Numbers Mean? $2^{\text {nd }}$ Edition. CSIRO Publishing.

[38] Hillette Hailu, Tekalign Mamo, Keskinen, R., Karltun, E., Heluf Gebrekidan and Taye Bekele. 2015. Soil fertility status and wheat nutrient content in vertisol cropping systems of central highlands of Ethiopia. Agriculture and Food Security, 4 (19).

[39] Jones, J. B. 2001. Laboratory guide for conducting soil tests and plant analysis. CRC press.

[40] Karltun, E., Mamo, T., Bekele, T., Gameda, S. and Kidanu, S. 2013. Ethiopian soil information system towards improved fertilizer recommendations in ethiopia. nutrient indices for categorization of fertilizer blends from EthioSIS District soil inventory data discussion paper.

[41] Katyal, J. C. and Randhawa. N. S. 1983. Micronutrients. FAO Fertilizer and Plant Nutrition Bulletin No. 7, Food and Agriculture Organization (FAO), Rome, Italy.

[42] Kedir Abate, Muktar Mohammed and Kibebew Kibret. 2016. Soil fertility assessment and mapping of spatial variability at Amareganda-Abajarso SubWatershed, North-Eastern Ethiopia. East African Journal of Sciences, 10 (1): 1-14.

[43] Kehali Jembere. 2017. Soil fertility assessment, Mapping and fertilizer type recommendation for Farta, Fogera, and Gondar Zuria districts in North western Amhara Regions, Ethiopia. $\mathrm{PhD}$ dissertation, Haramaya University, Haramaya, Ethiopia. 
[44] Landon, J. R. 1991. Booker tropical soil manual: A Handbook for soil survey and agricultural land evaluation in the Tropics and Subtropics. Longman Scientific and Technical, Essex, New York. 474p.

[45] Marschner, H. 1995. Mineral nutrition of higher plants. $2^{\text {nd }}$ edition. Academic Press, London.

[46] Matson PA, Naylor R, Ortiz-Monasterio I. 1998. Integration of environmental, agronomic, and economic aspects of fertilizer management. Science; 280: 112-5.

[47] Memon, N., Memon, K. S. and Ul-Hassan, Z. 2005. Plant analysis as a diagnostic tool for evaluating nutritional requirements of bananas. Review. International Journal of Agriculture and Biology, 7 (5): 824-831.

[48] Mesfin Abebe. 1996. The Challenges and future prospects of soil chemistry in ethiopia. pp. 78-96. In: TeshomeYizengaw, EyasuMekonnen and MintesinotBehailu (Eds.). Proceedings of the $3^{\text {rd }}$ Conference of the Ethiopian Society of Soil Science (ESSS). Feb. 28-29, 1996. Ethiopian Science and Technology Commission. Addis Ababa, Ethiopia. 272p.

[49] Mesfin Abebe. 1998. Nature and management of Ethiopian Soils. Alemaya University of Agriculture, Ethiopia. 272p.

[50] Mohammed Assen, P. A. L. Le Roux, C. H. Barker and Heluf Gebrekidan, 2005. Soils of Jelo Micro-catchment in the Chercher Highlands of Eastern Ethiopia: I. Morphological and Physico-chemical Properties. Ethiopian Journal of Natural Resources, 7 (1): 55-81.

[51] Mohammed Mekonnen, Kibebew Kibret, and Tekalign Mamo. 2016. Fertility mapping of some micronutrients in soils of Cheha district, Gurage zone, southern Ethiopia. African Journals of Soil Science, 4: 313-320.

[52] Moraghan, J. T. and Mascagni, H. J. 1991. Environmental and soil factors affecting micronutrient deficiencies and toxicities. In: Micronutrients in agriculture. Soil Science Society of America. Madison, WI, U.S.A, 371-425.

[53] Mulugeta Debele. 2018. Soil Characterization, Classification, Fertility Mapping and Physical Land Suitability Evaluation for Rain-fed Production of Major Crops at Muger Sub-watershed, Northern Oromia, Ethiopia. PhD dissertation, Haramaya University, Haramaya, Ethiopia.

[54] Murphy, H. F. 1968. A report on the fertility status and other data on some soils of Ethiopia, Experiment Station Bulletin No. 44, College of Agriculture Haile Sellassie I University, Dire Dawa, Ethiopia. 551p.

[55] Musefa Redi. 2016. Assessment of soil fertility status under striga hermonthica infested sorghum (sorghum bicolor 1. moench) fields at Pawe, Northwestern Ethiopia. MSc thesis. Haramaya University, Haramaya, Ethiopia.

[56] Nazif, W., Perveen, S. and Saleem, I. 2006. Status of micronutrients in soils of district Bhimber (Azad Jammu and Kashmir). Journal of Agricultural and Biological Science, 1 (2): 35-40.

[57] Okalebo, J. R., Gathua, K. W. and Womer, P. L. 2002. Laboratory Methods of Soil and Plant Analyses: a working manual, 2nd Edition. TSBF -CIAT and SACRED Africa, Nairobi, Kenya.

[58] Olsen, S. R., Cole, C. V., Watanabe, F. S. and Dean, L. A. 1954. Estimation of available phosphorus in soil by extraction with sodium bicarbonate. USDA circular 939: pp 1-19.

[59] Patel KP, Singh MV (2009). Scenario of micro - and secondary -nutrients deficiencies and their management in soils and crops of arid and semiarid regions of Gujarat. The Proceedings of the International Plant Nutrition Colloquium XVI, Department of Plant Sciences, UC Davis, UC Davis.

[60] Plank, C. O. and Donohue, S. J. 2000. Reference sufficiency ranges for plant analysis in the Southern Region of the United States. Southern Cooperative Series Bulletin \#394. p. 11-19.

[61] Rowell, D. L. 1994. Soil Science: Methods and Applications. Addison Wesley Longman Singapore Publishers (Pte) Ltd., England, UK. 350p.

[62] Sahlemedhin Sertsu and Taye Bekele. 2000. Procedures for soil and plant analysis. National Soil Research Organization, Ethiopian Agricultural Research Organization, Addis Ababa. 110p.

[63] Shlecht, E., A., Buerkert, E., Tielkes and A. Bationo, 2006. Critical Analysis of Challenges and Opportunities for Soil Fertility Restoration in Sudano-Sahelian West Africa. Nutrient Cycle and Agroecosystem; 76: 109-136.

[64] Swietlik, D. 1995. Interaction between zinc deficiency and boron toxicity on growth and mineral nutrition of sour orange seedlings. Journal of Plant Nutrition, 18: 1191-1207.

[65] Tegbaru Bellete. 2014. Fertility mapping of soils of AbayChomen district, Western Oromia, Ethiopia. MSc thesis. Haramaya University, Haramaya, Ethiopia.

[66] Tekalign Tadese. 1991. Soil, Plant, Water, Fertilizer, Animal Manure and Compost Analysis. Working Document No. 13. International Livestock Research Center for Africa, Addis Ababa, Ethiopia.

[67] Teklu Baissa, Suwanarit, A., Osotsapar, Y. and Sarobol, E. 2003. Status of $\mathrm{Cu}, \mathrm{Zn}, \mathrm{B}$ and $\mathrm{Mo}$ in agricultural soils of Western Ethiopia: Laboratory assessment. Journal of Natural Science, 37: 408-420.

[68] Tisdale, S. L., Nelson, W. L., Beaton, J. D. and Havlin, J. L. 1995. Soil Fertility and Fertilizer, $5^{\text {th }}$ Edition. Prentice-Hall of India, New Delhi. 684p.

[69] Usmael Mohammed. 2016. Soil fertility assessment and mapping of Becheke Sub-Watershed in Haramaya District of East Hararghe Zone of Oromia Region, Ethiopia. MSc thesis. Haramaya University, Haramaya, Ethiopia.

[70] Van Reeuwijk, L. P. 1992. Procedures for Soil Analysis, $3^{\text {rd }}$ Edition. International Soil Reference and Information Center (ISRIC), Wageningen, the Netherlands. 34p.

[71] Vanlauwe, B., F. Kanampiu, G. D. Odhiambo, H. De Groote, L. J. Wadhams and Z. R. Khan, 2008. Integrated Management of Striga hermonthica, Stem Borers, and Declining Soil Fertility in Western Kenya. Field Crops Research, 107: 102115.

[72] Wajahat, N., Sajida, P. and Iftikhar, S. 2006. Status of micronutrients in soils of District Bhimber (Azad Jammu And Kashmir). Journal of Agricultural and Biological Science, 1 (2): 35-40.

[73] Wakene Negassa and Heluf Gebrekidan. 2003. Forms of phosphorus and status of available micronutrients under different land-use systems of Alfisols in Bako area of Ethiopia. Ethiopian Journal of Natural Resources, 5 (1): 17-37. 
[74] Wakene Negassa. 2001. Assessment of important physicochemical properties of Dystric Udalf (Dystric Nitosols) under different management systems in Bako Area, Western Ethiopia MSc thesis. Haramaya University, Haramaya, Ethiopia.

[75] Walkley, A. and Black, I. A. 1934. An examination of the digestion method for determining soil organic matter and a proposed modification of the chromic acid titration method. Soil Science, 37: 29-38.

[76] Wolf, B. A. 1982. Comprehensive system of leaf analysis and its use for diagnosing crop nutrients status. Soil Science Plant Analysis, 13: 1035-1059.
[77] Wondoson Tena and Sheleme Beyene. 2011. Identification of growth limiting nutrient (s) in alfisols: soil physico-chemical properties, nutrient concentrations and biomass yield of maize. American Journal of Plant Nutrition and Fertilization Technology, 1: 23-35.

[78] Yifru Abera and Mesfin Kebede. 2013. Assessment on the status of some micronutrients in vertisols of the Central Highlands of Ethiopia. International Research Journal of Agricultural Science and Soil Science, 3 (5): 169-173.

[79] Zhihui, Y., Singh, B. R. and Hansen, S. 2007. Aggregate associated carbon, nitrogen and sulfur and their ratios in longterm fertilized soils. Soil and Tillage Research, 95: 161-171. 